\title{
Intelligence and Security Services Reform and Oversight in Ukraine - An Interim Report
}

\section{Philipp Fluri ${ }^{1}$ and Leonid Polyakov ${ }^{2}$}

\author{
1 Wenzao University, Taiwan, https://c041.wzu.edu.tw/ \\ 2 Center for Army, Conversion and Disarmament Studies, https://cacds.org.ua/
}

\begin{abstract}
Though Ukraine was among the first successor states of the Soviet Union to create a legal framework for the activities of its intelligence and security community, said framework addressed inherited and unreformed structures. Subsequent reform plans have not led to the success desired by Ukraine's international partners and, we must assume, a majority of the Ukrainian voters and taxpayers. Among the reform demands is also the credible subordination to parliamentary oversight, which, though stipulated by law, has effectively been neutralized by reference to subordination to the President in the same law. Who would want to be controlled by an ever-undecided parliament if a personalized oversight by the President and the expert committee of the National Security and Defence Council is the possible alternative? As a consequence, the Security Service of Ukraine (SSU) remains subject to much criticism - for the corruption of some of its representatives, for overlapping mandates with other security institutions, and for lack of control other than by itself and the changing presidents and their administrations.
\end{abstract}

Keywords: defense reform, intelligence reform, state security, state security reform, civilian oversight, parliamentary oversight, NATO, EUAM, DCAF, SSU, VR, Verkhovna Rada.

\section{Introduction}

In this article, we will look at three intelligence services of Ukraine and recent developments in their legal, managerial, and oversight structures: the Security Service of Ukraine (SSU - Sluzhba Bezpeky Ukrainy SBU, we use 'SSU' for the purposes of this article), the Main Intelligence Directorate of the Ministry of De- 
fense (Golovne Upravlinnia Rozvidky - GUR), and the Foreign Intelligence Service of Ukraine (Sluzhba Zovnishnioyi Rozvidky, further - SZR) - a political intelligence branch of the SSU, which was separated from the latter in 2005.

\section{A Brief History of Reform Plans for the SSU}

The Security Service of Ukraine (SSU) is the state's special purpose law-enforcement body, and by the existing law entrusted with a variety of mandates: to protect state sovereignty, the constitutional order, territorial integrity, the economic, scientific and technical, and defense potential of Ukraine, the state's legal interests and civil rights from intelligence and subversion activities of foreign services and from unlawful interference of organizations, groups, and individuals. It is also tasked with ensuring the protection of state secrets.

Currently, the SSU has a number of functions that overlap with the mandates of other institutions, including the fight against corruption. ${ }^{1, z}$

With more than 30,000 employees, the SSU is more than seven times the size of the UK's comparable service, the MI5. The Service's agents perform not only traditional intelligence-gathering and counterintelligence roles but also such roles as combating economic crimes utilizing the SSU investigative powers, which in most Western democracies would be seen as law-enforcement functions. This conglomerate of functions, some of them overlapping with those of other services, have created a hybrid animal difficult if not impossible to control, whose activities over the years have been overshadowed by accusations of blackmail, abuse of power, corruption, secret jails, extortion, and links to Russian security - in short, a service which Western counterparts are hesitant to engage with. Repeated calls for reform, including from within the Service, have not yet led to desired results.

Early discussions on SSU reform took place during the years the UkraineNATO Joint Working Group on Defense Reform (2005-2009) was active. A streamlining of the SSU's functions was again stipulated in the 2014 Parliamentary Coalition Agreement. In early 2016, a permanent international advisory group on the SSU reform was established with the participation of the represent-

1 The SSU was formed on September 20, 1990, as a successor service to the KGB branch in the Ukrainian SSR As such it inherited all of the Ukrainian KGB's personnel. The need to reform the service and give it a national profile was seen immediately after independence. The Ukrainian Parliament, the Verkhovna Rada (VR), adopted the pertinent Regulation On the Establishment of the National Security Service of Ukraine on 20 September 1991, with the Law On the Security Service of Ukraine to follow on March 25, 1992.

2 An English version of the currently valid Law "On the Security Service of Ukraine" (1992. Last revised in 2015) can be found in subsequent volumes of The Security Sector Legislation of Ukraine (published by NATO/DCAF/the Verkhovna Rada of Ukraine and the Defence and Security Council of Ukraine since 2002), e.g., in Oleksandr Lytvynenko, Philipp Fluri, and Valentyn Badrack, eds., The Security Sector Legislation of Ukraine (Geneva-Kyiv, 2017), 313-324, https://www.dcaf.ch/sites/default/files/pub lications/documents/Security\%20Sector\%20Legislation\%20Ukraine\%202017_eng.pdf. 
atives of the EU Advisory Mission for Civilian Security Sector Reform Ukraine (EUAM), the NATO Representation Office in Ukraine, the NATO Center for Information and Documentation in Ukraine, and other international organizations. ${ }^{3}$

A Concept paper for SSU reform based on NATO standards was drafted in July 2016 and submitted to state institutions for approval.

In March 2017, then-President Poroshenko announced a comprehensive reform of the SSU, aimed specifically at transferring part of its functions to other law-enforcement institutions - the National Anticorruption Bureau of Ukraine, the yet-to-be-organized State Bureau of Investigations, and the National Police.

Poroshenko also claimed that the reform would introduce civilian parliamentary oversight of the SSU. The National Security and Defence Council of Ukraine (NSDC) was supposed to review the Concept without delay. This is where the process has been stalling since, and revision of the existing Law on the Security Service of Ukraine effectively delayed. ${ }^{4}$

A comprehensive summary of the reform arguments pro and con can be found in the Proceedings of the Third International Conference on Governance and Reform of State Security Services in the Monitoring Ukraine's Security Governance Challenges cycle. ${ }^{5}$ It made the resistance of substantive parts of the staff to reforms (in times of war!) obvious, along with the relative powerlessness of civil society and the international advisors (the latter in fact going back to the activities of the Ukraine-NATO Joint Working Group on Defence Reform in 20052009).

In a gesture of openness, Andriy Bodrunov of the SSU Centre for Reform Support introduced the draft Concept of SSU Reform and the Plan for its Implementation until $2020^{6}$ to a public conference in 2017 . The plan for self-reform of the service foresaw, inter alia, the legislative separation of SSU tasks and powers

3 NATO representatives and European Union Advisory Mission in Ukraine (EUAM) collaborators even drafted a reform proposal in 2016 that was intended to name the necessary ingredients of such a reform policy in light of NATO member countries best standards. The proposal suggested to eliminate SSU law-enforcement functions and hand them over to the newly established National Anti-Corruption Bureau (NABU) and the National Police. That would leave the SSU to work strictly as an intelligence agency, focusing on counterespionage, counterterrorism, cybersecurity, and security analysis.

4 An argument frequently raised against parliamentary oversight is the allegation that MPs lacked the proper understanding of both intricacies of security work and its preconditions, such as secrecy. This in spite of the presence of retired intelligence officers among MPs - a fact which caused to the former Deputy Chairperson of the VR Oksana Syroid to speak of a "clash of civilisations" within the very parliament. See Philipp H. Fluri and Oleksiy Melnyk, eds., Citizens of Ukraine on Security: Personal, National, and its Elements - Survey 2 (Geneva/Kyiv, 2017), 11. Admittedly, subsequent parliaments have interpreted parliamentary immunity rather indulgently - for a discussion on parliamentary ethics and its excesses see Irina Suslova, Philipp Fluri, and Valentyn Badrack, Parliamentary Ethics in Ukraine (Kyiv-Geneva, 2017) [in Ukrainian].

5 Fluri and Melnyk, eds., Citizens of Ukraine on Security. Electronic versions of the publication to be found on ukrainesecuritysector.com, and academia.edu.

6 Fluri and Melnyk, eds., Citizens of Ukraine on Security, 16-19. 
from those of other intelligence and law-enforcement bodies of Ukraine, including those newly established, as well as the elimination of functions alien to the mandate of the SSU; the establishment of a credible civilian democratic oversight; the optimization of the organizational structure and adequate staffing, including the elimination of structures alien to the mandate; the provision of proper legal and social protection of service personnel; and the greater involvement of the special services of the SSU in international cooperation. ${ }^{7}$

As major objectives of the reforms were named increased public trust in the Service, including respect for its representatives; the enhancement of institutional capabilities of the Service as a specialized state body in the field of counterintelligence and the protection of state secrets, and as the main body within the national system for fighting terrorist activities; the separation of functional tasks and powers of the Service and other law-enforcement bodies and state bodies fighting corruption and organized crime, and protecting state interests in the economy, information and cyber sectors; a limitation of the pre-trial investigative powers of the Service, and the gradual demilitarization and optimization of the ratio of military to civilian positions in the Service in line with Ukraine's changing security environment.

\section{SSU Reform in the Zelensky Era}

In his inauguration speech on May 20, 2019, Ukrainian President Zelensky called on the Verkhovna Rada (VR, the Parliament of Ukraine) to dismiss the heads of the SSU, the Prosecutor General's Office, and the Defense Minister. SSU Head Vasyl Hrytsak then reportedly resigned on his own initiative.

New hands in both government and the international advisory teams took over after the 2019 elections, which brought a newly established political party to power, proving a rather complete disenchantment with 'old' elites (including those favored by Western political parties).

The slow reform of the SSU was again seen as a priority by the Deputy Head of the EU Advisory Mission Frederik Wesslau:

As for the reform of the Security Service of Ukraine, I think it is one of the most challenging but also one of the most needed reforms. It will require strong political will. ${ }^{8}$

According to Wesslau, the reform of the Security Service of Ukraine and parliamentary control are important because this will make the security sector more transparent and efficient and will increase the level of trust in Ukrainian security agencies. This would also strengthen democracy in the country. Reportedly,

7 Whereas it is true that cooperation between the SSU and Western services goes back to early post-Soviet years it is equally true that full cooperation among equals including comprehensive data exchange has not taken place until today (the authors).

8 "Wesslau: Reform of Ukraine's Security Service Is One of the Most Needed," ukrinform, May 23, 2019, https://www.ukrinform.net/rubric-defense/2706674wesslau-reform-of-ukraines-security-service-is-one-of-most-needed.html. 
"Zelensky and his team understand the need to report and set it as one of their priorities." According to Wesslau, drafted laws on reform will need to be reviewed: "we have seen the draft laws and do not think they meet Euro-Atlantic standards." ${ }^{9}$ That especially refers to parliamentary control. A further crucial aspect of interoperability was said to be the civilianization of the Service.

An International advisory group composed of representatives of the European Union, NATO, and the US participated in an August 13, 2019 meeting with (then acting) SSU head Bakanov and National Security and Defense Council chief Danyliuk on SSU reforms. Danyliuk was quoted by the BBC Ukrainian Service as saying a law was in preparation that would strengthen the SSU's core functions of "counterintelligence and combating terrorism."

\section{SSU Reform - Interim Observations}

In its own Ukrainian way, and possibly not yet adequately appreciated by its Western partners, the SSU has implemented at least some of its self-declared reform steps. Thus, the Service is about to succeed in giving itself a peoplefriendly image, protecting people's interests, and the nation's national and human values.

Public relations have become an important part of the image change. The Service frequently informs about its operations.

However, as long as the SSU remains porous vis-à-vis the Russian Security Service, with an over-fraught mandate, military structures, and without a credible parliamentary oversight by a credible parliamentary committee or subcommittee, Western services can be expected to stay at a distance. ${ }^{10}$

\section{Simple and Mixed Examples of Reform: GUR and SZR}

\section{Military Intelligence - GUR}

Rather different from the complex and heavily charged story of SSU is the simpler case of the Main Intelligence Directorate of the Ministry of Defense (Golovne Upravlinnia Rozvidky, further - GUR). The founders of the GUR had prior experience of service in the KGB military counterintelligence and the GRU

9 "Wesslau: Reform of Ukraine's Security Service."

10 Among the spectacular defections was former SSU head Oleksandr Yakymenko's flight to Russia, days after pro-Russian president Yanukovich had fled the country. Along with Yakymenko thousands of highly classified documents were said to have been irretrievably gone missing. After the Russian invasion of the Crimea a substantive number of Ukrainian SSU collaborators switched sides, not all of them leaving the Service. On April 14, 2020, the SSU announced the arrest of LTG Valeriy Shaytanov who had headed the anti-terrorist division playing a prominent role in negotiating ceasefires and prisoner exchanges with Russia-backed militants in Eastern Ukraine (April 14, 2020 15:58 GMTRFE/RL Ukrainian Service). Shaytanov stands accused of having provided information to Moscow about secret operations against Russia-backed separatists in eastern Ukraine and having recruited additional agents. 
(Glavnoe Razvedyvatelnoye Upravleniye) the Soviet Army's General Staff. However, contrary to the SSU, the GUR was created from scratch once Ukraine became independent from the USSR, and with a rather clear mandate. This naturally freed the GUR from the tail of bad habits and helped to build a purely national military intelligence agency in terms of spirit, organization, and oversight.

For about three decades, one did not hear much criticism of the agency, whether about its performance or its organization, which does not mean that there were no problems. Insiders and knowledgeable experts are aware of certain issues of personnel and operational-related nature, but these issues never caused much attention outside of the intelligence community. Besides, from the start of Russian aggression in 2014, the overall performance of the GUR has been seen mainly as positive. ${ }^{11}$ At least in the public eye.

Consequently, there was and is not much talk about reform of the GUR as an organization, especially when compared with SBU. However, in terms of democratic oversight standards, there are some nuances definitely deserving closer attention.

Though an agency formally subordinated to the MoD, the GUR de-facto enjoys a significant degree of independence from the Minister of Defense in terms of the budget and subordination. First, the GUR has its own line in the state budget completely independent of the MoD budget. Second, because of the complexity in the chain of command, where GUR is positioned as a servant of three masters. In addition to the traditional two-the civilian Minister of Defense and the uniformed general Commander-in-Chief of the Armed Forces-the Head of GUR has a direct reporting line to the Supreme Commander-in-Chief of the Armed Forces, the President. In the latter case, it means talking regularly not only to the President but also to select officials of the Presidential Administration and the leadership of the National Security and Defense Council headed by the President. Some former Heads of GUR were allegedly seen more often in the Presidential Administration than in the MoD.

In case the Head of GUR is a seasoned diplomatic person, this complexity in the executive oversight may not be a problem for GUR itself. However, this triple subordination contributes to the political weakening of the position of the Minister of Defense. It further limits the instruments of administrative control of the minister, who has no control over military counterintelligence (which belongs to the SSU), a merely symbolic military police (lacking operational-investigative powers), and limited control over military intelligence.

11 “(The) Ukrainian defense intelligence and the State Border Guard Service's intelligence arm are widely judged to have been performing effectively since the beginning of the 'hybrid war' with Russia." Maksym Bugriy, "Intelligence Reform in Ukraine Falls Short," Eurasia Daily Monitor 14, no. 106, September 6, 2017, https://jamestown.org/ program/intelligence-reform-in-ukraine-falls-short/. 


\section{Foreign Intelligence $-S Z R$}

GUR's sister agency-the foreign intelligence service of Ukraine (Sluzhba Zovnishnioyi Rozvidky, further - SZR) - is a political intelligence splinter of the SSU, which was separated from the latter in 2005. ${ }^{12}$ Therefore, internally, it inherited the institutional cultures and structures from the SSU. However, it inherited neither the political status and influence of the SSU nor (what became a real problem after the start of Russian aggression in 2014) an appropriate budget (which it still had while being part of the SSU).

Compared with SSU and GUR, the SZR is neither a simple nor a complex example of intelligence reform. On the one hand, there is a clear chain of command - the Head of the SZR is directly subordinated to the President. But on the other, in the absence of effective parliamentary control over intelligence in terms of proper expertise and oversight of personnel appointments, the Head of SZR and his deputies are hostages to one person's personal preferences and interests, of the President only. As a result, Ukraine has seen periods, even during the war, when the unwelcome Head of SZR could not personally meet the President for a very long time. Moreover, at times the top position at SZR has been vacant for over a year. Or recall the recent chain of appointments to the Head of SZR post for a period of just a few months.

Yet another side of the lack of effective parliamentary control over intelligence and unstable political support for the SZR in the Presidential Administration was the chronically low budget of the SZR. Between 2014 and 2018, it was critically low. ${ }^{13}$ For any intelligence service in a global environment, operating without money is close to nonsense. It is a big risk to national security, especially when at war with a regional superpower, heavily relying on its foreign intelligence instruments. Therefore, looking at the budgetary numbers, one does not need insider's knowledge to conclude that the foreign intelligence service of Ukraine is week and in need of reform, including budgetary reform.

As in the case of the SSU, there was not much evidence of any plan to reform the SZR for many years. ${ }^{14}$ In 2017-2019, facing growing criticism from the parliamentary committee on security and defense and the interested public, certain reforms of the SZR were conducted in accordance with the top-secret decree by President Petro Poroshenko, "On the Concept of Reforming the Foreign Intelli-

12 For details on the SZR earlier years, see: Leonid Polyakov, "Paramilitary Structures in Ukraine," in Almanac on Security Sector Governance in Ukraine 2010, edited by Merle Maigre and Philipp Fluri (Geneva: DCAF, 2010), 125-187, https://ukrainesecurity sector.com/wp-content/uploads/2016/01/Almanac-on-Security-Sector-Governancein-Ukraine-2010.-english.pdf.

13 See: "Foreign Intelligence Service Received only $8 \%$ of What it Needs, - MP Levus," CENZOR.NET, June 21, 2017, https://m.censor.net/news/445005/slujba_vneshneyi_ razvedki_profinansirovana_tolko_na_8_ot_potrebnosteyi_nardep_levus.

14 "The attitudes toward the complex task of reforming the SSU or the Foreign Intelligence Service could, heretofore, probably best be characterized as if it's not broken, don't fix it." Bugriy, "Intelligence Reform in Ukraine Falls Short." 
gence Service of Ukraine in Accordance with NATO Standards" of July 30, 2018. The SZR budget started to grow steadily from then on. ${ }^{15}$

Nevertheless, President Volodymyr Zelensky, elected in 2019, was apparently not impressed by the performance of the allegedly reformed SZR. During his first year in office, he substituted heads of the agency three times. In June 2020, during the ceremony of the introduction of his third appointee, former Head of GUR (in 2015-2016), LTG Valeriy Kondratiuk, President Zelensky specifically underlined the need for SZR reform and expressed expectations that the new Head would be able to conduct it successfully. ${ }^{16}$

\section{Conclusions}

Among the three services discussed, the creation of the Military Intelligence Service GUR was the least problematic. The SSU will remain problematic, at least in the eyes of Western experts and potential partners for closer cooperation, as long as its profile remains 'mixed' and thus indebted to the Service's past, combining intelligence with law-enforcement functions. The 'cultural' revolution necessary to make such transformation possible has not yet taken place. Subsequent teams of Western advisors to the Service and the political decision-makers, including in the VR, will have to deal with this.

To a degree, the slow pace of reforms in primary Ukrainian intelligence services is a result of being held hostage to the pace of political developments in Ukraine. Weak parliamentary control (inability to create an intelligence committee in the parliament), complicated system of executive control - all contributed to problems with intelligence budgets, delays upon delays in SSU reforms, agencies' leadership reshuffles, and limited cooperation with foreign partners from democratic countries.

15 See: "The Head of the Foreign Intelligence Service gave an interview for the journalists of LB.ua," LB.ua, January 24, 2019, https://lb.ua/news/2019/01/24/417974_egor_ bozhok_v_rf_reshenie.html.

16 See: "Zelenskyi set the task to reform the Foreign Intelligence Service," UKRINFORM, July 6, 2020, https://www.ukrinform.ru/rubric-polytics/3041917-zelenskij-porucilreformirovat-sluzbu-vnesnej-razvedki.html. 


\section{Disclaimer}

The views expressed are solely those of the authors and do not represent official views of the PfP Consortium of Defense Academies and Security Studies Institutes, participating organizations, or the Consortium's editors.

\section{Acknowledgment}

Connections: The Quarterly Journal, Vol. 20, 2021, is supported by the United States government.

\section{About the Authors}

Dr. Philipp H. Fluri - see the short CV on p. 7 of this issue

Leonid Polyakov is a former Deputy Defence Minister of Ukraine. Currently, he chairs the Expert Council at the Ukrainian think tank Center for Army, Conversion, and Disarmament Center.

E-mail: leonpol2006@gmail.com 